\title{
ON THE \\ DESTRUCTIVE EFFECT OF SMOKE IN RELATION TO PLANT LIFE.
}

\author{
By ARIHUR RIGG, \\ Member of Commil, Romal Botanir Society of London.
}

TIIE joint Committee of the Corl Smoke Abatement Society and The

1 Roval Sanitary Institute, having requested that some representative of the Ruyal Botanic Society should read a paper at the fortheoming Conference on the above subject, the Council of the Royal Botanic Soreiety have requested me to jerform this part, aud I trust to be able to add sumething of interest to rour proceedings.

The subject arose out of remarks in the Westminster Gasete on the evil conseguences of black smoke to the plants belonging to the Royal Botanic: Society. It has, however, been again and again before the Society, and no further back than $1880 \mathrm{Mr}$. Sowerby says: "Plants cultivated in London suffer at all times and seasons more or less from the dull atmosphere, charged as it is with smoke, and the muprecerlented annunt (in . annary, $18 s(0)$ and clumation of sont-charged fog which during many consecutive days hung were the Gardens, prevented the suns light from reaching the plants, and thus retarded their healthy levelopment. In some cases flower buds have fallen, without coming to maturity; in others umnitural and sickly growth has been the result, and this especially at the wreenhouses, the lower natural temperature of the open garden keeping the plants and trees generally in a state of sleep or rest, in which the action of light is not $s$ essential to their vitality."

So far as London is concerned, there seems to have been no appreciable juprovement or reduction in the number of its fogs, or their density, cluring the 25 years since that complaint was written, and the evergreens, with other plants, are still crusted as thickly as ever with a black slimy product which comes clown as fog. So damaging is this mud to the plant, that it beromes necessary to keep washing their leaves, and it may be taken as a general rulu that a London garden costs twice as much as a 
country garlen of the same size, and this is cutirely due to fogs and their constant companion smoke. Indeed, it is noticeable that West End gardens lose much of their due amount of sunshine owing to the pall of smoke (even when there is no fog) thit sunlight cannot penetrate, until high noon has passed, and the afternoons in West End gardens get far the largest amount of life-giving sunlight.

In considering the evil effects of coal-gas, when lumnt, upun the life of plants, and no doubt of animals also, it should be rememlererl that the carbon produced by imperfect combustion dus no direct or poisonous harm, but it closes up the pores of the leaves and prevents the performance of their proper functions.

As there is much sulphuric acid in the sulstance of the fog, it follows that a poisomous action takes placer, wherehy plants are greatly injured : it is, therefore, very desimble that there should oceasionally be a good top rleessing of the waste plaster of houses and ceilings, being pulled down, or lime where this camnot he got. This applies to window-box gardens, and to gardens of every size. Those plants which flower near the ground, such as pansies, suffer most from the poisonous surface of the ground, and no plants can be found which are in any way the better for the conditions under which they have to grow in a London garden.

In order to get some idlea of the amount of smoke or other items which fall upon the leaves of an evergreen plant (the ancuba), a (quantity has been gathered and carefully washed. The lifference in appearance of washed and unwashed leaves shows the extent of this eril, and it is no wonder that such a deposit dimages the plants that carry on a precarious existence in a London garden. The general consistency of the mul-ialen water ilproximates if it loes not exceed that of ink.

In order to learn which plants or trees can live or cannot live in I ondon, as compared with a clifferent climate, namely; that of his estate in Ireland, Mr. Marlay has leen making, luring many years past, a series of experiments, and the results he has most kindly supplied to the author, who has thus been enablerl to publish an extremely interesting comparison. It is curious to note that some plants, as for example the white oak (Quercus alba), will flourish in Regent's Park better than in Ireland, where it enjurs apparently the finest conditions.

It must be remembered that London has rariations of climate and more than one soil, and that fogs, inte which soot and sulphur largely enter, are prevalent during a sreat part of the year, Of trees generally, especially deciduous ones, such as the plane, several forms of acer, poplar and birch, will live fairly well in London atmosphere. The 
scarlet oak, introduced hy Mr. Marlay, hal surprised him hy its suceess up to the present.

In regard to common wild flowers, we must nut expect to wrow these with the same amount of success as we ciln do in a purer air.

Most rerareen shrubs are very doultful, and the pine tribe may be given up. Some evergreens will thrive woll for : certain time, the aucuba and broal-leaved holly being the best; others will struggle on like the yew and box, for varying periorls, but an of of nu use except in carcfully tended garrlens.

Fruit-trees might be tried in London on a more extended swale than at present. The experimental sarden belonging to the Royal Botanic Society shows very interesting examples of regetable and finit growth.

In conclusion, it an be taken as a greneral rule that all treces or plants with smonth leaves can better resist the action of fogs than thuse with rough or hairy leares, such as the foxglove, salvia, and rommon primrose. These and others of their class suffer the most injury.

So far as plants under glass are concerned, similar conditions parevail, affecting such plants as, for instance, the Chinese primulal and cincraria.

In all (ases, however, it is necessary to keep the wass clean by washing after the occurrence of $f_{0 g}$. 